\title{
UNDERSTANDING THE MOTIVATION TO INVEST: A PROFILE ANALYSIS OF ISLAMIC FUNDS' INVESTORS
}

\author{
Mohd Nizam Barom \\ International Islamic University Malaysia
}

\begin{abstract}
This paper seeks to provide a preliminary profile analysis of investors of Islamic funds based on their underlying motivation to invest, which at present received little interest in the literature. The experience of faith-based and socially responsible investment clearly reveals the heterogeneity of investors with divergent investment motives, and this is highly likely to be true among Islamic funds' investors as well. For this purpose, the study surveys Investors of Islamic funds from three fund management companies in Malaysia with a total sample of 451 respondents. The profiling employs a cluster analysis of the respondents using religion, percentage invested in Islamic funds, and four potential motivations to invest. The result shows a possible segmentation of the investors into three groups, with Muslim investors being segmented into two categories, 'committed' and 'pragmatic' investors, while the third category being the 'non-Muslim' investors. The clusters represent a clear distinction between the three groups in terms of their commitment to Shari'ah principles in investment, the importance of earning halal vis-à-vis high returns, and the benefits of diversification between Islamic and conventional funds. The findings provide valuable insights for fund management companies in terms of understanding the different segments of investors and their issues of concerns for better investment services, product innovation and offering, as well as marketing strategies.
\end{abstract}

Keywords: Islamic funds, profile analysis, investors' motivation, Islamic finance.

\section{INTRODUCTION}

The acceptance of equities as Shariah approved securities since the 1990s and the introduction of various Shariah indices globally have significantly contributed to the strong growth of Islamic funds industry worldwide. Additionally, the introduction of other asset classes, such as Shariahcompliant securities in the money and capital markets, has increased the breadth of Funds categories available for investment. Accordingly, the rapid expansion of the Islamic funds industry has attracted a lot of research interests in various dimensions of the industry. Nevertheless, as surveyed by Masih et al. (2016), studies on the Islamic funds industry have been largely quantitative and empirical in nature, particularly in the area of performance, portfolio diversification, risk-return characteristics, market timing ability, trading strategies, and efficiency. This tendency is largely driven by the apparent limitations faced by Islamic funds in terms of creating an optimal investment portfolio and achieving competitive performance in the face of the limited investable universe of permissible securities (Karim et al., 2013). Another area that receives considerable interests is the investigation on the industry's Shari'ah screening and compliance aspects (Khatkhatay \& Nisar, 2007; Derigs \& Marzban, 2008; Rahman et al., 2010; Clarke, 2015). However, studies examining the profile and underlying motivation that drives the investment behaviour among investors of Islamic funds are still scanty, with most of the work focusing on the determinants influencing the investment choice or portfolio allocation particularly in relation to the religiosity factor (Tahir \& Brimble, 2011; Jamaludin, 2013; Mahdzan 


\section{The Journal of Muamalat and Islamic Finance Research}

et al., 2017).

Islamic investment is not the only industry which is founded by religious-ethical values; the Western ethical or socially responsible investment (SRI) industry has been adopting various forms of faith-based, ethical, social, environmental and governance screens since the 1960s and can be considered as more mature in terms of its investment strategies and industry size. The growth of SRI industry globally has been frequently associated with the increasing investors' demand for their investment to be in line with their religious, ethical, social or environmental convictions. Nevertheless, the SRI literature clearly reveals the divergent motives of various groups of SRI investors (Kinder, 2005; Sandberg et al., 2009; Pérez-Gladish et al., 2012; Barom, 2019), and this may also be the case among investors of Islamic funds as well. Hence, this paper seeks to add to the literature by providing a preliminary profile analysis of Islamic funds' investors based on their underlying motivation to invest. This can have significant implications to both investors and fund managers. On one hand, understanding the motivation to invest enable fund managers to address the concern of the investors more effectively, and therefore serves the interest of the investors. On the other hand, profile information of investors can facilitate better marketing strategy and further product innovation among fund managers in the Islamic investment industry.

In the light of the forgoing introduction, this paper proceeds as follows, surveys the literature in the area constituting mainly the insights from the ethical and socially responsible industry on possible segmentation and profile analysis of investors. Subsequently, discusses the data and method, i.e. the instrument used, respondents involved in the survey and the clustering technique used in the analysis. Next, presents the analysis and findings of the study, starting with the initial descriptive analysis of the responses, followed by a cluster analysis procedure for a possible segmentation of the investors based on six key variables, i.e. religion, percentage invested in Islamic funds, and four potential motivations to invest. Lastly, concludes the paper by summarising the important findings of the study.

\section{LITERATURE REVIEW}

Given the scant literature in the area of investors' profile within the field of Islamic investment, this study seeks to benefit from the available literature in the socially responsible investment (SRI) industry. In SRI, investors who invest based on ethical, religious, social or environmental criteria can come from various backgrounds, and may often have differing motives when making SRI investment (Kinder, 2005; Sandberg et al., 2009; Barom, 2019). For instance, value-based investors commit to align their investment with their personal values or religious belief. In doing so, these investors choose to avoid from investing in activities that contradict their values. In fact, findings showed that value-based investors are willing to sacrifice some financial returns for the sake of SRI (which reflects their strong commitment) (Webley et al., 2001; Pasewark \& Riley, 2010). On the other hand, another group of investors consider the exclusionary strategy, i.e. avoiding investing in companies or activities that contradict their ethical convictions, as a 'passive' approach and insufficient, and prefer a more 'active' approach by channelling their investment in a way that can promote positive impact on the society or the environment (EuroSIF, 2006; Dembinski et al., 2003).

It is also common for SRI investors to have SRI based investments and at the same time, hold other non-SRI related investment (Nilsson, 2008; Lewis \& Mackenzie, 2000). Some considered this behaviour as an attempt to balance two conflicting motives; to avoid the feeling of guilt if not acting in a way that is consistent with their ethical conviction, while at the same time, would prefer not to substantially sacrifice financial returns from investment. In other words, such a pragmatic behaviour is consistent with the principle of 'not putting all the eggs in one basket', even if this involved a matter of conviction or principles (Lewis, 2001). Findings have also shown that financial motive has a significant influence on the level of such commitment; e.g. the percentage of total investment invested in SRI is influenced by its expected 


\section{The Journal of Muamalat and Islamic Finance Research}

financial returns (Nilsson, 2008) and the willingness to sacrifice financial return among SRI investors depends on the level of returns they received from the regular (non-SRI) investment (Glac, 2009). This entails that the principle of diversification, whether as a mean of freeing the feeling of one's guilt, or as a component of one's diversified portfolio, can be an important motivation in the investment decision making process.

With the rapid growth of SRI and the popular belief that investing based on social, ethical or environmental criteria may not necessarily result in lower returns, and in some cases, may even over-perform its conventional counterpart, another distinct type of SRI approach has emerged in the late 90s and is identified by Kinder (2005) as Value-Seeking SRI. Unlike valuebased investors, value-seeking investors search for the social and environmental aspects of businesses which may affect financial performance and apply them as financial selection criteria to achieve higher returns. The fact that SRI related investments can provide competitive or even higher returns may well mean that there can be some group of investors who invest with purely financial concern without sharing the SRI cause. Therefore, it is important to understand the investors' underlying motivation with respect to their investment decision in order to have an accurate insight to their investment behaviour. As highlighted in the literature of SRI (Nilsson, 2009); "when treating all socially responsible investors as one group, it becomes difficult to draw conclusions about the behaviour, since the reason that the behaviour is performed is not known." In brief, we can have at one end of the spectrum investors who are highly committed to the extent that they are willing to sacrifice financial return to achieve their cause, while at the other extreme, there are some investors who use social responsibility criteria as a mere instrument to seek investment prospect with higher financial returns (Dembinski et al., 2003; Kinder, 2005; Barom, 2019).

Similarly, it cannot be assumed that all investors of Islamic funds have homogeneous motive. While complying to Shariah principles and to be true to one's religious and ethical convictions could be the primary motive among some investors (Yusuff \& Mansor, 2016), other motives, such as found in the SRI literature are highly probable. Evidences leading to this can be seen in the literature of Islamic banking. As surveyed by Barom (2013), the empirical findings on the behaviour and patronage decisions among depositors and customers of Islamic banks revealed mixed motives, with numerous studies showing returns and costs factors overwhelming religious considerations. Therefore, it is imperative to understand the underlying motivation of the investors with respect to their decision to invest in Islamic funds, as this would provide a valuable insight for Islamic fund management companies to profile their investors.

\section{METHODOLOGY}

\section{Instrument}

The review of literature on SRI has identified several motivations which may influence investors to subject their investment decision on certain ethical concerns. Among others, they include the need for investors to align their investment with their ethical conviction, affect positive change in the society, as well as benefit from diversification (Kinder, 2005; EuroSIF, 2006; Rhodes \& Soobaroyen, 2010). In fact, SRI decisions may well have a mix of both profit-driven self-interest motive and altruistic motive (Nilsson, 2008, 2009; Pérez-Gladish et al., 2012; Barom, 2019). Based on these literatures, four possible motivations to invest are included in a questionnaire. The question reads- Why do you invest in Islamic funds? The responses were 'I want to earn halal returns from my investment', 'I invest because it gives high returns', 'I want my investment to be used in economic activities that have positive impact to the society', and 'I want to diversify my investment with conventional funds.' The items were measured on a five-point Likert scale ranging from 'Not important at all (1)' to 'Very important (5)'. Except for 'I want to earn halal returns from my investment', other items for the motivation were adapted from previous SRI studies as reviewed in literature review. In addition to the basic motivation to invest, two other important information related to the study were the respondents' religion and the proportion of 


\section{The Journal of Muamalat and Islamic Finance Research}

investment they invested in Islamic funds in comparison to the overall unit trust investments. In the context of Muslim investors, this would reflect their level of commitment in observing the Shariah principles in their investment decision.

Apart from the key variables as described above, that are important to the cluster analysis, the questionnaire has also included three additional items which may provide further information on the motivation of the investors. The respondents were asked to state their level of agreement (or disagreement) on the following statements; 'I expect Islamic funds to provide at least similar returns as compared to conventional funds', 'I am prepared to accept lower returns from my investment as long as it is based on Islamic principles', and 'Investment that is based on Islamic principals are more resilient against fluctuations in the market'. The items were also measured on a five-point Likert scale ranging from 'Not important at all (1)' to 'Very important (5)'. The items used in this study were extracted from a questionnaire designed for a larger study on the issue of 'social responsibility dimension in Islamic investment funds' (Barom, 2015, 2019).

\section{Respondents}

This study involved a questionnaire survey among investors of Islamic funds using a purposive sampling method from three fund management companies in Malaysia: Public Mutual Berhad, CIMB-Principal Asset Management Berhad, and Prudential Fund Management Berhad. These management companies represent different sizes in the Malaysian fund management industry. The survey was conducted through a network of agents and agency branches of the three fund management companies located in different areas of Kuala Lumpur, the financial centre of Malaysia. A total of 1250 questionnaires were distributed from which 451 questionnaires were returned, with a response rate of 36.1 percent. The inclusion of respondents from three different fund management companies increases the representativeness of the study as compared to if the survey is conducted among the investors from only one fund or company, as in the case with some previous SRI studies.

Male respondents formed 58.1 percent of the total sample while female respondents were 41.9 percent. The proportion of male and female respondents across different demographic variables closely approximates the total sample proportion. Apart from the responses received from the ethnic Malays, which formed about 80 percent of the total respondents, the survey also included a total of 73 (16.2 percent) respondents from the Chinese ethnic and 17 (3.8 percent) from the Indian ethnic. In terms of religion, a total of 363 (80.7 percent) respondents were Muslims, 43 (9.6 percent) were Buddhist, 29 (6.4 percent) were Christians while 11 (2.4 percent) were Hindus. A cross tabulation of ethnicity by religion showed that all Malay respondents were Muslim, while another 3 Muslim respondents came from the Indian ethnic. As the distribution of investors of Islamic funds between ethnic and religion in the Malaysian market is not known, direct comparison between the sample and the population cannot be made. Nevertheless, the participation of investors from other faiths contributes to a comprehensive outlook of the study and is representative of the actual population. On another note, it appears that Islamic investment products are also marketable and consumed by fellow Malaysians from other faiths. 


\section{The Journal of Muamalat and Islamic Finance Research}

\section{Clustering method}

Cluster analysis is a statistical technique widely used to group or classify the units under study by identifying groups of individuals or objects that are similar to each other, but different from individuals in other groups. For instance, it has been employed to group SRI investors based on their objective in SRI investment (Nilsson, 2009). There are three types of clustering procedures commonly available in statistical packages, i.e. hierarchical cluster, $\mathrm{k}$-means cluster, and two-step cluster analysis. Hierarchical cluster analysis is suitable for a small data set and a very useful tool to examine solutions with increasing numbers of clusters. On the other hand, if the desired number of clusters is already known, k-means clustering will provide a good classification and is suitable for a moderately sized data set. The two-step procedure, on the other hand, is appropriate for a large data file or an analysis with a mixture of continuous and categorical variables. This study aims to segment and profile respondents based on their motivation to invest in Islamic funds. The four items included in the questionnaire to represent the basic motivations to invest were measured in the form of Likert scales. Additionally, as the decision is also believed to be influenced by religious factor; religion is also identified as an important grouping variable. However, being Muslim alone may not necessarily imply that the respondents will strictly comply with the Shariah principles in their investment decision.

Therefore, the respondents' choice of investment, i.e. the percentage invested in Islamic funds from overall unit trust investment is an important variable in reflecting the level of commitment. As a result, four scaled items and two categorical variables are used to group the respondents with the aim of segmenting the respondents and understanding their profile. Based on the above description, the two-step procedure is the most appropriate technique as it allows the use of categorical and continuous variables to be included in the analysis. By default, all variables included in the two-step procedure will be automatically standardised. Another interesting feature of this method is that the algorithm employed can automatically select the optimal number of clusters, either using the Schwarz Bayesian Criterion or the Akaike information criterion (Norusis, 2005). The validity and utility of the results can be determined based on several criteria. Among others, all clusters should have reasonable number of cases and the meaning of each cluster should be readily intuited from the constituent variables used to create the clusters.

\section{RESULTS}

\section{Descriptive analysis}

Based on the literature of SRI and Islamic investment, four basic motives are listed in the questionnaire to understand the underlying motivation of the investors. Respondents were asked to rate the importance of each when they decide to invest in Islamic funds. Table 1 presents the frequencies, means and standard deviations of the four basic motives.

Table 1: Respondents' Underlying Motivation When Investing in Islamic Funds

\begin{tabular}{|c|c|c|c|c|c|c|}
\hline Items & $\begin{array}{c}\text { Not } \\
\text { Important }\end{array}$ & Neutral & Important & Mean & $\begin{array}{c}\text { Std. } \\
\text { Deviation }\end{array}$ & $\mathbf{N}$ \\
\hline I want to earn halal returns. & $\begin{array}{c}43 \\
(9.7 \%)\end{array}$ & $\begin{array}{c}49 \\
(11.0 \%)\end{array}$ & $\begin{array}{c}355 \\
(79.4 \%)\end{array}$ & 4.293 & 1.0742 & 447 \\
\hline $\begin{array}{l}\text { I want to diversify my } \\
\text { investment with conventional } \\
\text { funds. }\end{array}$ & $\begin{array}{c}152 \\
(36.1 \%)\end{array}$ & $\begin{array}{c}89 \\
(21.1 \%)\end{array}$ & $\begin{array}{c}180 \\
(42.8 \%)\end{array}$ & 2.988 & 1.3723 & 421 \\
\hline $\begin{array}{l}\text { I invest because it gives high } \\
\text { returns. }\end{array}$ & $\begin{array}{c}14 \\
\left(3.2^{\%} \%\right)\end{array}$ & $\begin{array}{c}80 \\
(18.3 \%)\end{array}$ & $\begin{array}{c}343 \\
(78.5 \%)\end{array}$ & 4.096 & .8459 & 437 \\
\hline $\begin{array}{l}\text { I want my investment to be } \\
\text { used in economic activities } \\
\text { that have positive impact to } \\
\text { the society. }\end{array}$ & $\begin{array}{c}21 \\
(4.8 \%)\end{array}$ & $\begin{array}{c}107 \\
(24.3 \%)\end{array}$ & $\begin{array}{c}313 \\
(71.0 \%)\end{array}$ & 3.952 & .8893 & 441 \\
\hline
\end{tabular}


By looking at the standard deviation of the four items (Table 1), it can be observed that the first two items seemed to have greater dispersion as compared to the other two. The respondents comprised of various ethnic and religious groups, including the non-Muslims, and these investors may hold varying proportion of their overall unit trust investment in Islamic funds. In view of this, earning halal returns, which basically reflects the religious motive of Muslim investors will not be shared by investors from other faiths. Similarly, while some investors would consider diversification benefit between conventional and Islamic funds as important in their investment decision, those investors who strictly commit to Shariah principles would reject any investment in non-Shariah compliant products, and hence consider the potential diversification between Islamic and conventional funds to be irrelevant.

On the other hand, a closer agreement can be found in terms of the financial motives of the investment with substantial number of respondents expressed the importance of high returns in their investment decision. As shown in Table 1, financial concerns were shared by most investors regardless of their background. Similar observation can also be said for the social objective of the investment. Though be it at a relatively lower level of magnitude, most investors recognised the importance of investing in economic activities that have positive impact to the society when making investment in Islamic funds.

Table 2: Percentage Invested in Islamic Funds

\begin{tabular}{|c|c|c|}
\hline $\begin{array}{l}\text { Percentage Invested in } \\
\text { Islamic Funds }\end{array}$ & $\begin{array}{c}\text { No. of } \\
\text { Respondents }\end{array}$ & Percent \\
\hline Less than $20 \%$ & 38 & 8.4 \\
\hline $20-39 \%$ & 54 & 12.0 \\
\hline $40-59 \%$ & 49 & 10.9 \\
\hline $60-79 \%$ & 49 & 10.9 \\
\hline $80-99 \%$ & 29 & 6.4 \\
\hline $100 \%$ & 229 & 50.8 \\
\hline Total & 448 & 99.3 \\
\hline \multirow[t]{2}{*}{ No Response } & 3 & .7 \\
\hline & 451 & 100.0 \\
\hline
\end{tabular}

Another important finding from the survey is regarding the proportion of funds the respondents invested in Islamic funds in comparison to the overall unit trust investment. In the context of Muslim investors, this will reflect their commitment in observing the Shariah principles in their investment decision. As shown in Table 2, slightly more than half of the respondents held all their unit trust investment in Islamic funds, while the remaining had varying percentages of their overall investment held between Islamic and conventional funds. A cross tabulation of religion by the percentage invested in Islamic funds reveals that almost all respondents who held all their unit trust investment in Islamic funds were Muslims. However, this was not the case for more than a third of the Muslim investors as they held different proportion of their unit trust investment in conventional funds. This suggests that while religion (Islam) may be a strong factor in guiding the investment decision for some Muslim investors, it does not provide enough influence over others.

It is also interesting to compare the stated motivation to invest (Table 1) with the actual investment behaviour (Table 2) among the respondents. For instance, the cross tabulation shown in Table 3 reveals that despite expressing the importance of 'halal' returns from investment, around one-third of Muslim investors held varying percentage of non-Shariahcompliant funds. While a religious factor can be an important element in guiding investment decision, this cannot be generalised to all Muslims as depicted in Table 3. Some Muslims do not even consider 'earning halal returns' to be an important reason when making investment in Islamic funds. 
Table 3: Cross-Tabulation of 'I Want to Earn Halal Returns from My Investment' by Percentage Invested in Islamic Funds Among Muslim Investors

\begin{tabular}{|c|c|c|c|c|c|c|c|c|}
\hline & & $\begin{array}{l}\text { Less } \\
\text { than } \\
20 \%\end{array}$ & $20-39 \%$ & $40-59 \%$ & $60-79 \%$ & $80-99 \%$ & $100 \%$ & Total \\
\hline \multirow{6}{*}{$\begin{array}{l}\text { I want to } \\
\text { earn } \\
\text { halal } \\
\text { returns } \\
\text { from } \\
\text { my } \\
\text { investment }\end{array}$} & Not & 2 & 0 & 0 & 0 & 0 & 0 & 2 \\
\hline & Important & $(100.0 \%)$ & $(.0 \%)$ & $(.0 \%)$ & $(.0 \%)$ & $(.0 \%)$ & $(.0 \%)$ & $(0.6 \%)$ \\
\hline & Neutral & $\begin{array}{c}2 \\
(9.5 \%)\end{array}$ & $\begin{array}{c}6 \\
28.6 \%)\end{array}$ & $\begin{array}{c}5 \\
(23.8 \%)\end{array}$ & $\begin{array}{c}3 \\
(14.3 \%)\end{array}$ & $\begin{array}{c}2 \\
(9.5 \%)\end{array}$ & $\begin{array}{c}3 \\
(14.3 \%)\end{array}$ & $\begin{array}{c}21 \\
(5.8 \%)\end{array}$ \\
\hline & Important & 4 & 18 & 3 & 13 & 2 & 25 & 65 \\
\hline & & $\left(6.2^{\%}\right)$ & $(27.7 \%)$ & $(4.6 \%)$ & $(20.0 \%)$ & $(3.1 \%)$ & $(38.5 \%)$ & $(18.1 \%)$ \\
\hline & $\begin{array}{l}\text { Very } \\
\text { Important }\end{array}$ & $\begin{array}{c}16 \\
\left(5.9^{\circ} \%\right)\end{array}$ & $\begin{array}{c}12 \\
(4.4 \%)\end{array}$ & $\begin{array}{c}13 \\
(4.8 \%)\end{array}$ & $\begin{array}{c}14 \\
(5.1 \%)\end{array}$ & $\begin{array}{c}21 \\
(7.7 \%)\end{array}$ & $\begin{array}{c}196 \\
(72.1 \%)\end{array}$ & $\begin{array}{c}272 \\
\left(75.6^{\circ} \%\right)\end{array}$ \\
\hline Total & & $\begin{array}{c}24 \\
(6.7 \%)\end{array}$ & $\begin{array}{c}36 \\
(10.0 \%)\end{array}$ & $\begin{array}{c}21 \\
(5.8 \%)\end{array}$ & $\begin{array}{c}30 \\
(8.3 \%)\end{array}$ & $\begin{array}{c}25 \\
(6.9 \%) \\
\end{array}$ & $\begin{array}{c}224 \\
(62.2 \%)\end{array}$ & $\begin{array}{c}360 \\
(100 \%)\end{array}$ \\
\hline
\end{tabular}

\section{Cluster Analysis}

Consistent with the literature in SRI, the descriptive analysis has shown that investors of Islamic funds can also consist of diverse groups that may have differing motives. Recognising this, this paper proceeds with a cluster analysis based on their responses to six questionnaire items related to their motivation to invest in Islamic funds. In addition to the responses to the items shown in Table 1, two categorical variables namely religion and the percentage invested in Islamic funds were also included in the analysis. While religious commitment is expected to be an important element in the investment decision for Muslim investors, the percentage invested in Islamic funds will reflect the actual extent in which such a commitment is upheld.

Using the above variables, a two-step cluster analysis was employed and the Results are shown in Table 4, 5 and $\mathbf{6}$. As discussed earlier in methodology, the algorithm employed within the two-step cluster procedure can automatically select the optimal number of clusters using the Schwarz Bayesian Criterion or the Akaike information criterion. In this case, both criteria had identified three appropriate clusters for the respondents based on the variables used in the analysis and this is shown in Table 4. A total of 83 respondents were clustered in cluster 1, 131 or 31.7 percent were in cluster 2 while the remaining 199 or 48.2 percent were grouped in cluster 3.

Table 4: Distribution of Respondents Based on Cluster Membership

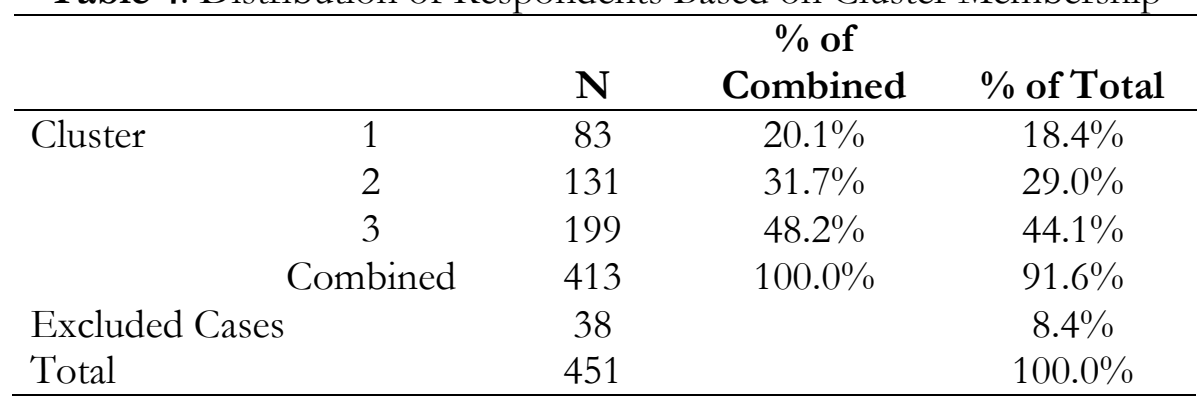

Due to some missing values, only a total of 413 respondents were included in the cluster analysis. In order to interpret the results, it is important to examine the characteristics of the variables associated with each of the cluster. Table $\mathbf{5}$ shows the results of the cluster analysis based on the two categorical variables included in the analysis. It is quite apparent that religion had played a major role in the identification of the cluster membership. All 83 respondents grouped in cluster 1 are non-Muslims, while Muslim investors were split into either cluster 2 with 131 respondents or cluster 3 with 199 respondents. The information related to the percentage 
invested in Islamic funds provides additional explanation on the cluster distribution. The result shows that respondents who were grouped in cluster 2 had investment both in conventional and Islamic funds while those grouped in cluster 3 had all their unit trust investment in Islamic funds. As the two clusters consist of all Muslims, this suggests that there exists some distinction on the underlying motivation of Muslim investors based on their actual investment decision. However, this is not applicable to investors from other faiths as they were grouped in cluster 1 despite that a few of them ( 3 respondents) have all their unit trust investment in Islamic funds.

Table 5: Distribution of Respondents' Religion and Percentage Invested in Islamic Funds According to Cluster Membership

\begin{tabular}{|c|c|c|c|c|c|}
\hline & & \multicolumn{4}{|c|}{ Cluster Membership } \\
\hline & & 1 & 2 & 3 & Total \\
\hline \multirow[t]{5}{*}{ Religion } & Islam & $\begin{array}{c}0 \\
(.0 \%)\end{array}$ & $\begin{array}{c}131 \\
(39.7 \%)\end{array}$ & $\begin{array}{c}199 \\
(60.3 \%)\end{array}$ & $330(79.9 \%)$ \\
\hline & Christianity & $\begin{array}{c}28 \\
(100.0 \%)\end{array}$ & $\begin{array}{c}0 \\
(.0 \%)\end{array}$ & $\begin{array}{c}0 \\
(.0 \%)\end{array}$ & $28(6.8 \%)$ \\
\hline & Buddhism & $\begin{array}{c}41 \\
(100.0 \%)\end{array}$ & $\begin{array}{c}0 \\
(.0 \%)\end{array}$ & $\begin{array}{c}0 \\
(.0 \%)\end{array}$ & $41\left(9.9^{\%} \%\right)$ \\
\hline & Hinduism & $\begin{array}{c}10 \\
(100.0 \%)\end{array}$ & $\begin{array}{c}0 \\
(.0 \%)\end{array}$ & $\begin{array}{c}0 \\
(.0 \%)\end{array}$ & $10(2.4 \%)$ \\
\hline & Others & $\begin{array}{c}4 \\
(100.0 \%)\end{array}$ & $\begin{array}{c}0 \\
(.0 \%)\end{array}$ & $\begin{array}{c}0 \\
(.0 \%)\end{array}$ & $4(1.0 \%)$ \\
\hline \multirow{6}{*}{$\begin{array}{c}\text { Percentage } \\
\text { Invested in } \\
\text { Islamic } \\
\text { Funds }\end{array}$} & $\begin{array}{c}\text { Less than } \\
20 \%\end{array}$ & $\begin{array}{c}13 \\
(35.1 \%)\end{array}$ & $\begin{array}{c}24 \\
(64.9 \%)\end{array}$ & $\begin{array}{c}0 \\
(.0 \%)\end{array}$ & $37(9.0 \%)$ \\
\hline & $20-39 \%$ & $\begin{array}{c}17 \\
(34.0 \%)\end{array}$ & $\begin{array}{c}33 \\
(66.0 \%)\end{array}$ & $\begin{array}{c}0 \\
(.0 \%)\end{array}$ & $50(12.1 \%)$ \\
\hline & $40-59 \%$ & $\begin{array}{c}27 \\
(57.4 \%)\end{array}$ & $\begin{array}{c}20 \\
(42.6 \%)\end{array}$ & $\begin{array}{c}0 \\
(.0 \%)\end{array}$ & $47(11.4 \%)$ \\
\hline & $60-79 \%$ & $\begin{array}{c}19 \\
(38.8 \%)\end{array}$ & $\begin{array}{c}30 \\
(61.2 \%)\end{array}$ & $\begin{array}{c}0 \\
(.0 \%)\end{array}$ & $49(11.9 \%)$ \\
\hline & $80-99 \%$ & $\begin{array}{c}4 \\
(14.3 \%)\end{array}$ & $\begin{array}{c}24 \\
(85.7 \%)\end{array}$ & $\begin{array}{c}0 \\
(.0 \%)\end{array}$ & $28(6.8 \%)$ \\
\hline & $100 \%$ & $\begin{array}{c}3 \\
(1.5 \%)\end{array}$ & $\begin{array}{c}0 \\
(.0 \%)\end{array}$ & $\begin{array}{c}199 \\
(98.5 \%)\end{array}$ & $202\left(48.9^{\%} \%\right)$ \\
\hline Total & & $\begin{array}{c}83 \\
(20.1 \%)\end{array}$ & $\begin{array}{c}131 \\
(31.7 \%)\end{array}$ & $\begin{array}{c}199 \\
(48.2 \%)\end{array}$ & $413(100.0 \%)$ \\
\hline
\end{tabular}

Table 6 presents the results of the cluster analysis based on the four items reflecting the underlying motivation to invest in Islamic funds. For the first motive, which is to earn 'halal' returns from investment, the highest level of importance came from the respondents of cluster 3 with a mean score of 4.854, followed by cluster 2 with 4.397 , while cluster 1 only had a mean score of 2.651 .

Table 6: Mean and Standard Deviation on the Underlying Motivation to Invest in Islamic Funds According to Cluster Membership

\begin{tabular}{cccccc}
\hline Items & & Cluster & Cluster & Cluster & Combined \\
& & $\mathbf{1}$ & $\mathbf{2}$ & $\mathbf{3}$ & \\
\hline I want to earn halal returns & Mean & 2.651 & 4.397 & 4.854 & 4.266 \\
& Std. Dev. & .9931 & .7813 & .3942 & 1.0779 \\
I want to diversify my investment & Mean & 3.566 & 3.336 & 2.492 & 2.976 \\
with conventional funds & Std. Dev. & .9395 & 1.1342 & 1.4937 & 1.3704
\end{tabular}




\section{The Journal of Muamalat and Islamic Finance Research}

\begin{tabular}{cccccc} 
I invest because it gives high returns & Mean & 3.952 & 4.000 & 4.206 & 4.090 \\
& Std. Dev. & .9094 & .7545 & .8485 & .8385 \\
I want my investment to be used in & Mean & 3.277 & 3.855 & 4.281 & 3.944 \\
$\begin{array}{c}\text { economic activities that have } \\
\text { positive impact to the society }\end{array}$ & Std. Dev. & .8310 & .8514 & .7462 & .8837 \\
\hline
\end{tabular}

Even though both cluster 2 and 3 consist of all Muslim investors, the highly ranked mean score for cluster 3 with a substantially low standard deviation (0.3942) show how strong this motive was in their investment decision, separating them from their fellow Muslims investors in cluster 2. The differences in the mean responses suggest a varying degree of importance of complying with the principles of Shariah in the investment decision. As this is not applicable for investors from other faiths, it explains the low importance of this objective for the respondents in cluster 1.

Substantial variation on the scores of importance can also be observed between clusters with respect to the second item related to the diversification motive. The respondents in cluster 1 (which consists of non-Muslim investors) ranked relatively important the significance of diversification motive between the two types of funds with a mean score of 3.566. The results for cluster 2 and 3, on the other hand, accentuate further the distinction between the two groups of Muslim investors with a mean score of 3.336 for cluster 2 and 2.492 for cluster 3 .

The apparent distinction between cluster 2 and 3 in both above motives (earning 'halal' returns and diversification) can be explained by looking at the percentage they invest in Islamic funds. As previously described, the respondents in cluster 3 only invest in Islamic funds. This would suggest their strong commitment to comply with the principles of Shariah and avoid any investment that contradicts their conviction. On the other hand, as Muslims, respondents of cluster 2 still recognise the importance of earning 'halal' returns, but nevertheless compromise the injunctions of Shariah by having some portions of their investment in conventional funds. Accordingly, this behaviour reveals a pattern of a pragmatic approach by these respondents in their investment decision. Based on the data, and to achieve clarity in subsequent discussions and analysis, cluster 3,2 and 1 are hence forth referred as 'committed' investors, 'pragmatic' investors, and 'non-Muslim' investors respectively.

The results for the fourth motive which relates to investing in economic activities that have positive impact on the society are consistent with the understanding that has been established so far on the characteristics of the three clusters. The mean scores for 'committed' and 'pragmatic' investors were 4.281 and 3.855 respectively, while the value for the 'non-Muslim' investors was relatively lower at 3.277. The higher level of importance that the 'committed' investors attached to this motive as compared to the 'pragmatic' investors and the 'non-Muslim' investors may be the result of the ethical dimension embraced by the 'committed' investors in line with their commitment to the Shariah principles in their investment choices.

Despite the earlier differences, the three clusters seemed to have an equal agreement on the level of importance of earning 'high returns' when making investment in Islamic funds. The mean scores for 'committed' investors, 'pragmatic' investors and 'non-Muslim' investors were 4.206, 4.000 and 3.952 respectively. Therefore, regardless of the Shariah compliant nature of the funds, or the types and background of the investors, profit motive remains an important element in the investment decision making of most investors.

\section{Further Profiling of the Clusters}

Apart from the key variables used above in the cluster analysis to group investors based on their underlying motivation to invest in Islamic funds, the questionnaire has also included three additional items that may provide further information on the profile of the clusters. The respondents were asked to state their level of agreement (or disagreement) on their expectation on the returns from Islamic funds as compared to conventional funds, the willingness to sacrifice 


\section{The Journal of Muamalat and Islamic Finance Research}

returns for complying with the principles of Shariah and the perception towards the resilience of investment based on Shariah principles against market volatility. As shown in Table 7, it appears that for all the three statements, there is a consistent ranking of agreement in terms of the highest mean score with 'committed' investors showing the highest values, followed by the 'pragmatic' investors and the 'non-Muslim' investors.

Table 7: Additional Profiling of the Investors

\begin{tabular}{|c|c|c|c|c|}
\hline Items & & $\begin{array}{c}\text { Non- } \\
\text { Muslim } \\
\text { Investors }\end{array}$ & $\begin{array}{l}\text { Pragmatic } \\
\text { Investors }\end{array}$ & $\begin{array}{l}\text { Committed } \\
\text { Investors }\end{array}$ \\
\hline I expect Islamic funds to provide at & Mean & 3.325 & 3.977 & 4.352 \\
\hline $\begin{array}{l}\text { least similar returns as compared to } \\
\text { conventional funds }\end{array}$ & $\begin{array}{l}\text { Std. } \\
\text { Dev. }\end{array}$ & 1.1594 & .8177 & .7226 \\
\hline I am prepared to accept lower & Mean & 2.494 & 3.389 & 3.970 \\
\hline $\begin{array}{l}\text { returns from my investment as long } \\
\text { as it is based on Islamic principles }\end{array}$ & $\begin{array}{l}\text { Std. } \\
\text { Dev. }\end{array}$ & .9156 & 1.0196 & .9151 \\
\hline Investment that is based on Islamic & Mean & 3.651 & 3.878 & 4.152 \\
\hline $\begin{array}{l}\text { principles is more resilient against } \\
\text { fluctuations in the market }\end{array}$ & $\begin{array}{l}\text { Std. } \\
\text { Dev. }\end{array}$ & .9030 & .7128 & .8353 \\
\hline
\end{tabular}

It is quite interesting to see that despite the commitment shown by the 'committed' investors in complying with the injunctions of Shariah in their investment; they expressed a relatively high level of agreement towards the expectation of earning similar returns in comparison with the conventional funds with a mean score of 4.352. This is compared to a more modest mean score for the 'pragmatic' investors (3.977) and a relatively indifferent attitude of the 'non-Muslim' investors (3.325). Nevertheless, the strong commitment of the 'committed' investors is clearly reflected in their willingness to sacrifice financial returns to comply with the principles of Shariah in investment with a mean score of 3.970. The mean scores for 'pragmatic' and 'non-Muslim' investors for this item were 3.389 and 2.494 respectively. While there were substantial variations in the mean scores among the clusters in the above two items, all the three clusters expressed relatively similar attitudes towards the resilient nature of Islamic investment against market volatility. The mean score was 4.152 for the 'committed' investors, 3.878 for the 'pragmatic' investors and 3.651 for the 'non-Muslim' investors.

'Committed' investors place high importance of earning 'halal' returns from investment and this has been clearly demonstrated by their actual investment behaviour. Since a commitment to Shariah principles limits their investment universe to only Islamic funds, it is important for them that the Islamic funds provide comparable returns with the conventional funds. This will not be as important for the 'non-Muslim' investors or even for the 'pragmatic' investors as they have the flexibility of choosing between the two types of funds. On the other hand, in the case where complying with the Shariah principles in investment can result in lower returns, the 'committed' investors are willing to make this sacrifice, reflecting their strong commitment to the Shariah principles. This is, however, not the case for 'pragmatic' investors, as they have shown a relatively indifferent attitude towards this issue. This information strengthens our understanding of the results of the cluster analysis previously employed. Despite being Muslims and believe in the importance of earning 'halal' returns from investment, the 'pragmatic' investors hold some proportions of their investment in conventional funds and recognise the importance of diversification benefits between Islamic and conventional funds when making investment decision. This reflects the pragmatic approach adopted by these investors and therefore, explains their unwillingness to sacrifice financial returns in order to comply with the Shariah rules. As for the 'non-Muslim' investors, it is understandable that complying with Shariah principles is not part of the consideration, and therefore, sacrificing financial returns for 


\section{The Journal of Muamalat and Islamic Finance Research}

this purpose is irrelevant. As previously shown, investors from other faiths invest in Islamic funds to seek high returns and benefit from diversification. The importance of diversification motive in their investment of Islamic funds can be explained by their relative belief on the resilience of Islamic investment against market volatility.

\section{CONCLUSION}

This paper has provided a preliminary profile analysis of Islamic funds' investors based on their underlying motivation to invest. The descriptive analysis has shown that, even though a majority of the Muslim respondents invest only in Shariah compliant investment, more than a third of them held different proportion of their unit trust investment in conventional funds. Consistent with the literature in SRI, the descriptive analysis has shown that investors of Islamic funds can also constitute diverse groups that may have differing motives. Subsequently, a cluster analysis is employed to provide additional insight in the potential segmentation of the investors. Based on the items representing the underlying motivations when investing in Islamic funds and two categorical variables (religion and percentage invested in Islamic funds), the cluster algorithm has identified three appropriate clusters; with Muslim investors were clustered into two different groups. Subsequent profiling analysis have later labelled these groups as committed, pragmatic and non-Muslim investors.

The findings revealed that Muslim investors, in general, consider earning halal return from investment as the most important motivation when investing in Islamic funds and are willing to sacrifice financial returns to comply with the Shariah principles in investment. While most of them reflects such a commitment by having all their investment in Shariah-compliant funds (committed investors), quite a sizeable number of them holds different proportion of their investment in conventional funds (pragmatic investors). In fact, some of the pragmatic investors acknowledge the importance of the diversification benefits between Islamic and conventional funds. On the other hand, investors from other faiths invest in Islamic funds to seek high returns and benefit from diversification; and most of them believe that such funds are more resilient against market volatility.

Despite the exploratory nature of this study, it provides important initial insights on the motivation underlying the investment decision and the profile of Islamic funds' investors which can be an important reference work for future studies in the area. Additionally, the findings can serve as important inputs to Islamic fund management companies to improve on their investment services, product innovation and offering, as well as marketing strategies for a continuous development of the industry.

\section{REFERENCES}

Barom, M. N. (2013). Conceptualizing a strategic framework of social responsibility in Islamic economics. International Journal of Economics, Management and Accounting, 21 (1), 65-95.

Barom, M. N. (2015). Social Responsibility Dimension in Islamic Investment: A Survey of Investors' Perspective in Malaysia. In Hatem A. El-Karanshawy et al. (Eds), Ethics, Governance and Regulation in Islamic Finance, Volume 4 (pp. 91-104). Bloomsbury Qatar Foundation, Doha.

Barom, M. N. (2019). Understanding socially responsible investing and its implications for Islamic investment industry. Journal of Emerging Economies and Islamic Research, 7(1), 1-13.

Clarke, K. A. (2015). A critical analysis of Islamic equity funds. Journal of Islamic Accounting and Business Research, 6(1), 107 - 121.

Dembinski, P. H., Bonvin, J. M., Dommen, E. \& Monnet, F. M. (2003). The ethical foundations of responsible investment. Journal of Business Ethics, 48(2), 203-213.

Derigs, U. \& Marzban, S. (2008). Review and analysis of current shariah-compliant equity screening practices. International Journal of Islamic and Middle Eastern Finance and Management, 1(4), 285-303. 


\section{The Journal of Muamalat and Islamic Finance Research}

EuroSIF. (2006). European Sri Study 2006. European Social Investment Forum.

Glac, K. (2009). Understanding socially responsible investing: The effect of decision frames and trade-off options. Journal of Business Ethics, 87(1), 41-55.

Jamaludin, N. (2013). Religion and individual investment choice decision: The case of Malaysia. International Journal of Business and Social Science, 4(1), 104-113.

Karim, M. R. A., Asutay, M., Shafii, Z. \& Aris, M. M. (2013). Examining Islamic funds underperformance: The case of Malaysia. The Journal of Muamalat and Islamic Finance Research, 10(1), 125-143.

Khatkhatay, M.H. \& Nisar, S. (2007). Shariah compliant equity investments: An assessment of current screening norms. Islamic Economic Studies, 15(1), 47 - 76.

Kinder, P. D. (2005). Socially responsible investing: An evolving concept in a changing world. Boston, MA: KLD Research \& Analytics.

Lewis, A. (2001). A focus group study of the motivation to invest: 'Ethical/green' and 'ordinary' investors compared. Journal of Socio-Economics, 30(4), 331-341.

Lewis, A. \& Mackenzie, C. (2000). Morals, money, ethical investing and economic psychology. Human Relations, 53(2), 179-191.

Mahdzan, N. S., Zainudin, R., Che Hashim, R. \& Sulaiman, N. A. (2017). Islamic religiosity and portfolio allocation: The Malaysian context. International Journal of Islamic and Middle Eastern Finance and Management, 10(3), 434-452.

Masih, M., Kamil, N. K. \& Bacha, O. I. (2016). Issues in Islamic equities: A literature survey. Emerging Markets Finance and Trade, 54(1), 1-26.

Nilsson, J. (2008). Investment with a conscience: Examining the impact of pro-social attitudes and perceived financial performance on socially responsible investment behavior. Journal of Business Ethics, 83(2), 307-325.

Nilsson, J. (2009). Segmenting socially responsible mutual fund investors: The influence of financial return and social responsibility. International Journal of Bank Marketing, 27(1), 5-31.

Norusis, M. J. (2005). SPSS 13.0 statistical procedures companion. Upper Saddle River, N.J.: Prentice Hall.

Pasewark, W. R. \& Riley, M. E. (2010). It's a matter of principle: The role of personal values in investment decisions. Journal of Business Ethics, 93(2), 237-253.

Pérez-Gladish, B., Benson, K. \& Faff, R. (2012). Profiling socially responsible investors: Australian evidence. Australian Journal of Management, 37(2), 189-209.

Rhodes, M. J. \& Soobaroyen, T. (2010). Information asymmetry and socially responsible investment. Journal of Business Ethics, 95(1), 151.

Sandberg, J., Juravle, C., Hedesström, T. M. \& Hamilton, I. (2009). The heterogeneity of socially responsible investment. Journal of Business Ethics, 87(4), 519-533.

Rahman, A. A., Yahya, M. A. \& Nasir, M. H. M. (2010). Islamic norms for stock screening: A comparison between the Kuala Lumpur Stock Exchange Islamic Index and the Dow Jones Islamic Market Index. International Journal of Islamic and Middle Eastern Finance and Management, 3(3), 228-240.

Tahir, I. \& Brimble, M. (2011). Islamic investment behavior. International Journal of Islamic and Middle Eastern Finance and Management, 4(2), 116-130.

Webley, P., Lewis, A. \& Mackenzie, C. (2001). Commitment among ethical investors: An experimental approach. Journal of Economic Psychology, 22(1), 27-42.

Yusuff, N. \& Mansor, F. (2016). Proposed model for the factors influencing Muslim investors in choosing Islamic unit trust funds. Journal of Global Business and Social Entrepreneurship, 1(2), 113-120. 